\title{
Payment for Environmental Services as a Strategic Tool for the Environmental Conservation of a Micro-Basin in the Amazon Region
}

\author{
Cruz Delmivam Souza, ${ }^{1}$ Kaminshi Tatiana Cristina Guimarães, ${ }^{2}$ Pereira Júnior Antônio ${ }^{3 *}$ \\ ${ }^{1}$ State University of Para, Brazil \\ ${ }^{2}$ Federal University of Parana, Brazil \\ ${ }^{3}$ State Univerisity of Pará, Environmental Quality Laboratore, Brazil
}

\begin{abstract}
The work considered as hypothesis the conflicting relationship between the man and the nature, and it analyzed the disordered occupation of the Amazon basin with focus in the study area. The implications and transformations of the deforestation and use of the soil that cannot impact the supplying areas of goods and Environmental and ecosystem Services, the adverse effects that the climatic changes have been provoking in the water cycle in the Amazon, with mismanagement of use of natural resources, what raises the negative externalities. It was possible to notice that even after years of occupation and devastation of the Amazon forest, threats and pressures are recurrent, marked by the "drag effect", where investment in major projects, infrastructure, easy access to forested areas, and therefore, the biodiversity and the ecosystems of the region are disastrously destroyed. These human actions have caused a reckless future scenery, so, the study analyzed the possibility of integrating the existing instruments Payment Tool for Environmental Services (PSA), an assertive and willful way can promote changes in the management model, sustainable development of the rural properties, with good practices of use and occupation of the soil, with a view to the restoration or recovery of APP and water recharge area of the area of interest. On the other hand, to owners who re-adapt their properties to the proposed management model, with soil and water conservation practices, adequate management of RL, APP, in order to reduce the percent of soil erosion and to preserve the springs, watery eyes and the drainage of the Uraim River, in the suggestion, will be, inputs, appropriate technical knowledge of land use, inputs and financially rewarded.
\end{abstract}

Keywords: Amazon, Ecosystem, Deforestation

\section{Introduction}

Over the past three decades, discussions on improving environmental management in watersheds have intensified regarding payment for water use. This issue is part of the Payment for Environmental Services (PES), which uses it as a tool for the conservation of natural areas or the recovery of anthropized areas that generate ecosystem services. ${ }^{1}$

PSA is an improvement of environmental management, where good environmental practices are recognized and rewarded, this management mechanism is on the agenda, because it has an inte grative and conciliatory character of interests. ${ }^{2,3}$ At the same time, there are advances and modernizations in federal, state and municipal laws with the objective of promoting the conservation of environmentally sensitive areas in each biome. ${ }^{4}$

However, the perception of users of this natural resource, about this system of environmental management, law enforcement, and the monitoring of environmental conservation of the water body is ineffective. Therefore, there are no guarantees of environmental adjustments on rural properties and, therefore, is doomed to exhaustion. ${ }^{5,6}$
Quick Response Code:

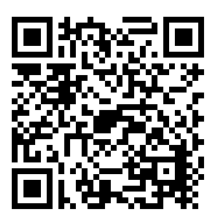

*Corresponding author: Pereira Júnior Antônio, State Univerisity of Pará, Environmental Quality Laboratore, Highway 125, Street Angelim, Paragominas, Para, Brazil

Received: 06 February, 2021

Published: 11 March, 2021

Citation: Cruz DS, Kaminshi TCG, Pereira JA. Payment for Environmental Services as a Strategic Tool for the Environmental Conservation of a Micro-Basin in the Amazon Region. Glob Scient Res Env Sci. 2021;1(3):1-9. DOI: 10.53902/GSRES.2021.01.000511 
PSA is an environmental awareness mechanism that implements economic, social and ecological value to nature, regardless of the monetary allocation to ecosystem services. In addition, this system establishes guarantees for the provision of environmental services, and is also an instrument that can promote preventive and corrective action in a sustainable manner. According to Forest Trends, Katoomba Group, UNEP ${ }^{7}$ the PES system adopted in Costa Rica, Ecuador, Bolivia, India, Africa, Mexico and the United States maximizes the positive effects of the ecosystems of the watershed with the system of natural filters, mitigates disasters and catastrophes, regulates floods and fosters the local economy.

With this, PSA has been used as an economic, effective and assertive tool, as it provides a voluntary transaction between landowners who provide desired environmental services, and the purchaser of services that may be users, government or non-governmental organizations, known as NGOs. ${ }^{4,7}$ All the arguments reported justified this survey, and the generation of data on them is of paramount importance and relevance for the elaboration of municipal public policies.

As for the objectives: (1) To analyze, in a qualitative way, the margins of the Uraim River, upstream of the point of capture, in the South direction, as to the technology and activity of land use and occupation and the possible impacts generated; (2) To carry out a critical analysis of the study area as to APP, consolidated area, Legal Reserve (RL), native vegetation and, if necessary, suggest methods of recovery; (3) To identify possible financing sources, responsible for investment in the promotion of environmental adequacy of rural properties, and emphasize proactive actions.

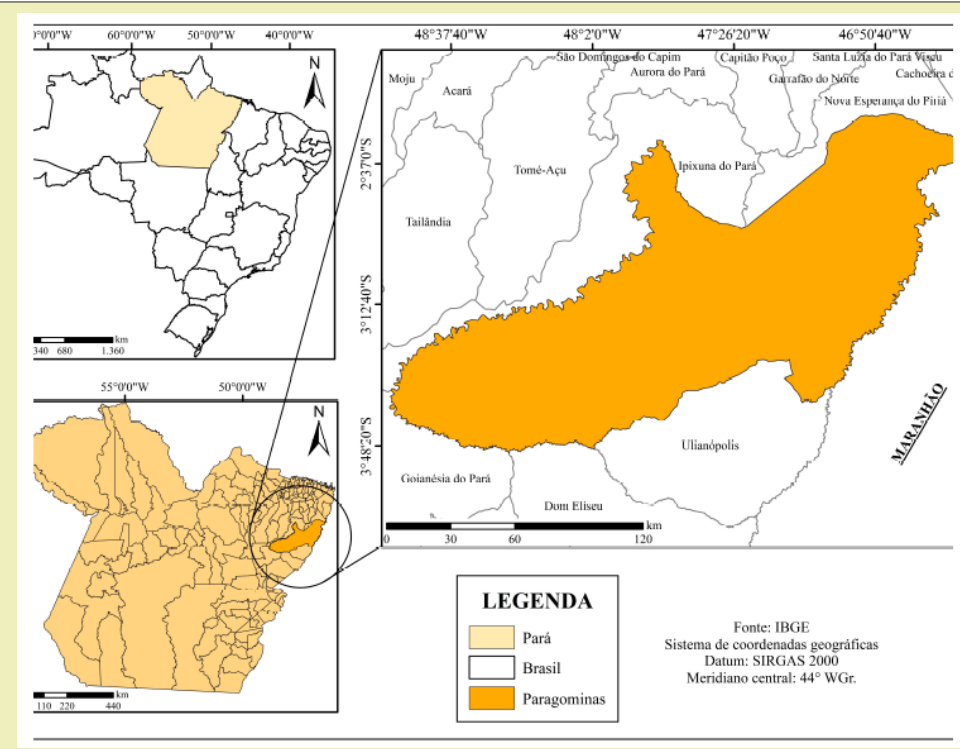

Figure 1: Location of the study area. Paragominas - PA Source: IBGE; SICAR. $^{22}$

\section{Materials and Methods}

\section{Characterization of the study area}

The study area (Figure 1), is located in the Western Northeast Atlantic hydrographic region, in northeast Pará, on the banks of BR Bernardo Sayão (BR 010), 310km from the capital Belem, in the rural area of the municipality of Paragominas, upstream of the SANEPAR company's catchment point, on the Uraim River, with an area of 43,093.36ha. In 2017 Paragominas had an estimated population of 110,026 inhabitants, distributed in 1,934,186ha, demographic density of 5.06..$^{8,9}$ The municipal headquarters is located in the geographical coordinates: North (latitude) $03^{\circ} 00^{\prime} 00^{\prime \prime S}$ and East (longitude) $47^{\circ} 21^{\prime} 21^{\prime} \mathrm{W}$, Zone/Zone 23, Southern Hemisphere. ${ }^{10}$

According to Martins et al. ${ }^{11}$ the municipality of Paragominas-PA has a mesothermic and humid climate, with average annual temperatures close to $26.3^{\circ} \mathrm{C}$ and relative air humidity of $85 \%$. The average annual rainfall $1,790 \mathrm{~mm}$, average flow of $2,683 \mathrm{~m}^{3} / \mathrm{s}$, evapotranspiration $1.482 \mathrm{~mm}$, it is important to note that due to seasonality, about $80 \%$ of precipitation occurs in the period from
December to June. ${ }^{12}$ The soil is characterized in $95 \%$ of the territory, as the type, yellow latosols, clay with little fertility, rich in aluminum, and, the vegetation coverage was by dense forest of alluvial plain. However, anthropic actions originated forest degradation in $45 \%$ of the municipality of Paragominas. ${ }^{10}$

The hydrography of the municipality consists of two basins, the Capim, with ramifications over $54 \%$ of the area of the municipality, and Gurupi, occupies 46\% remaining, and is composed of six sub-basins: Maritaca, Piriá, Croatá, Poraci-Paraná and Uraim, where the study area is located..$^{13}$

In 2007, Paragominas-PA was included by the MMA in the list of municipalities that deforested the Amazon forest the most, and the Federal Police carried out the "Arc of Fire" operation, with various consequences, impossibility of applying for credits in public banks, several logging and agricultural companies were closed in the municipality, causing socio-economic chaos in the region. ${ }^{14}$

In view of this, the townspeople represented by organized civil entities signed a term against deforestation, and the "Green Munic- 
ipality" Program was instituted, with partnerships with NGOs, the Institute of Man and the Environment of the Amazon (IMAZON) and The Nature Conservancy (TNC) aiming at sustainable development, with environmental campaigns, satellite monitoring, and the registration of $80 \%$ of rural properties. The results were immediate; with a $90 \%$ reduction in deforestation and the MMA removed the municipality from the blacklist of those who deforest most. ${ }^{15}$

\section{Data collection and analysis}

The method applied was the deductive, ${ }^{16}$ because it was based on two true premises: (1) there are no studies, in the municipality of Paragominas, regarding the ecosystem services provided by water bodies; (2) environmental valuation and the willingness to pay for the maintenance of these services by users of water bodies.

Regarding the research, it is of qualitative approach (the information obtained is analyzed in an inductive way); as for nature, it is observational and visual, because it expands the knowledge about PSA; with exploratory purpose because it intends to make familiar the objective of the study, that is, PSA and, finally, the procedure adopted was that of bibliographic research about the use or not of payment for environmental services in Paragominas - $\mathrm{PA}^{17}$ and visit in loco. The secondary data were obtained from the SICAR link, in the State of Pará, with a temporal cut-off from 2012 to 2018.

First, the secondary data were downloaded from the SICAR website, in Shapefile format; they were organized and worked on in the ArcGis 10.1 software, designed in DATUM 2000 in UTM 23M format. After that, the Clips of the area of interest were made and the maps were made with the classification already proposed and inserted in the classifications available in the site. Based on these data, analysis of possible environmental liabilities in the Uraim River micro-basin, upstream of the water catchment point, with analysis of the properties, by means of maps, and the activities carried out in these rural properties, were carried out.

To filter the data in a coherent way to promote a clear reading of the maps, ArcGis in version 10.1 was used to process the data and generate in-depth and illustrative environmental information of the Uraim River basin upstream of the water catchment point to supply the city of Paragominas. As well, the hydro-environmental situation was verified and if necessary, suggest recovery methods for ecosystem water services by the PES method to environmental service providers.

\section{Presentation of Results}

The polygon demarcates the study area (Figure 2), where it is possible to highlight the boundaries of the properties in green, and the areas of properties declared to SICAR in yellow. The total area of the declared study area is approximately 43,093.36ha. The farms, sites and communities located over the Uraim microbasin in the study area can collaborate negatively or assertively in the environmental management of ecosystem services, and in the quality and quantity of water

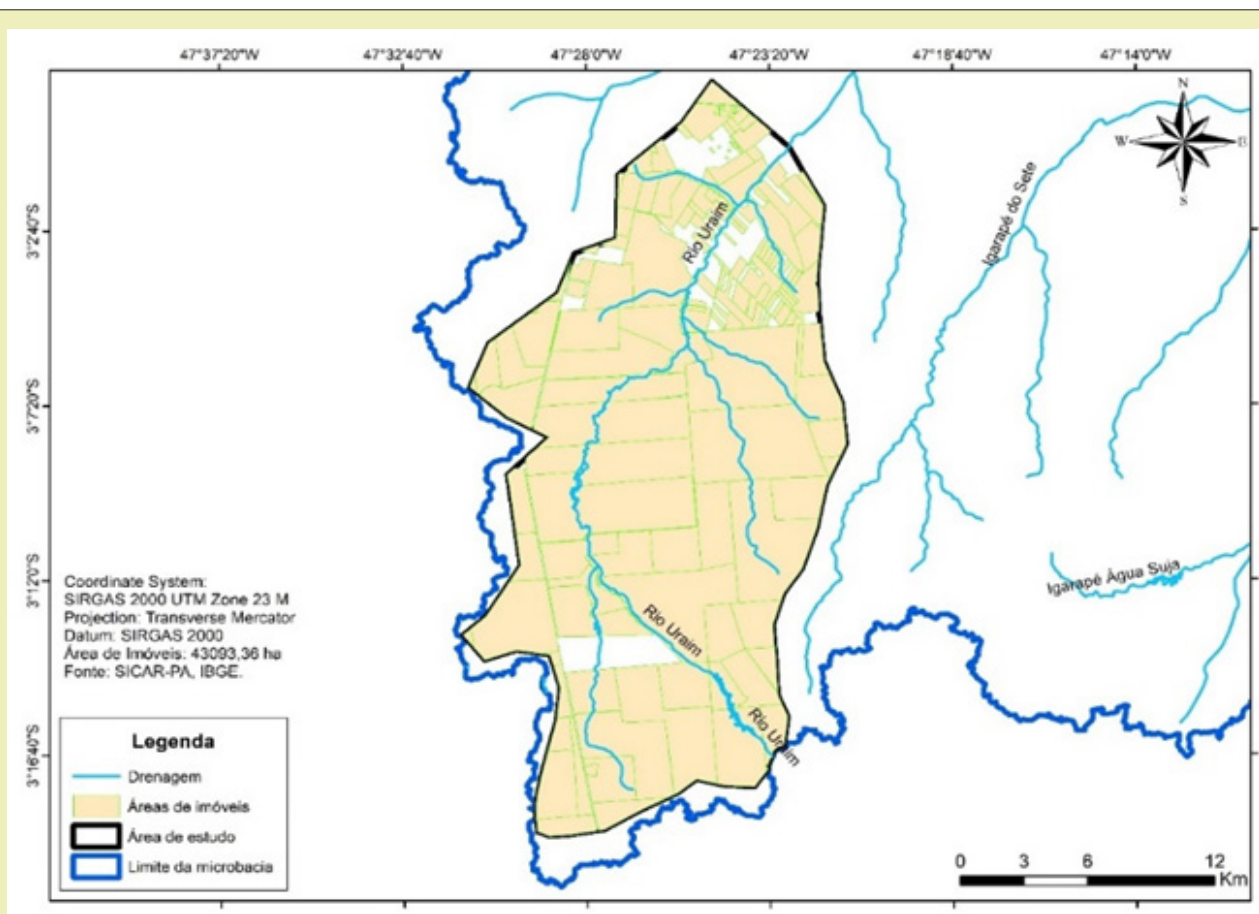

Figure 2: Real estate areas declared to SICAR in the study area. Paragominas - PA.

Source: IBGE; ${ }^{8}$ SICAR. ${ }^{22}$

There is concurrent and diverse demand (rural demand, animal dessedentation, irrigation, industrial and urban), and the company SANEPAR serves $47 \%$ of the urban population, with flow of $180 \mathrm{~L} / \mathrm{s}$ of the Uraim River plus 9 (nine) wells, and at the end of the year will move to $360 \mathrm{~L} / \mathrm{s}$ to meet $100 \%$ of the urban population of the municipality. ${ }^{18}$ According to estimates, the demand for water consumption in rural communities to meet human needs is 70 to $120 \mathrm{~L} /$ hab/day, and, to meet the needs of animals, cattle, is on average $50 \mathrm{~L} /$ animal/day and, birds, on average $0.4 \mathrm{~L} /$ bird/day. ${ }^{12}$ 
According to Pinto et al., ${ }^{13}$ the municipality of Paragominas develops several economic activities: cattle raising, timber (sustainable management of wood), reforestation, bauxite mining, cultivation of soybeans, corn, rice, etc. The studied polygon does not differ from the rest of the municipality, according to the data contained in the CAR, the activities developed in the properties are: agriculture, cattle raising, transformation of agricultural or cattle raising products, reforestation, forest management, etc., and, some properties had activities developed without information.

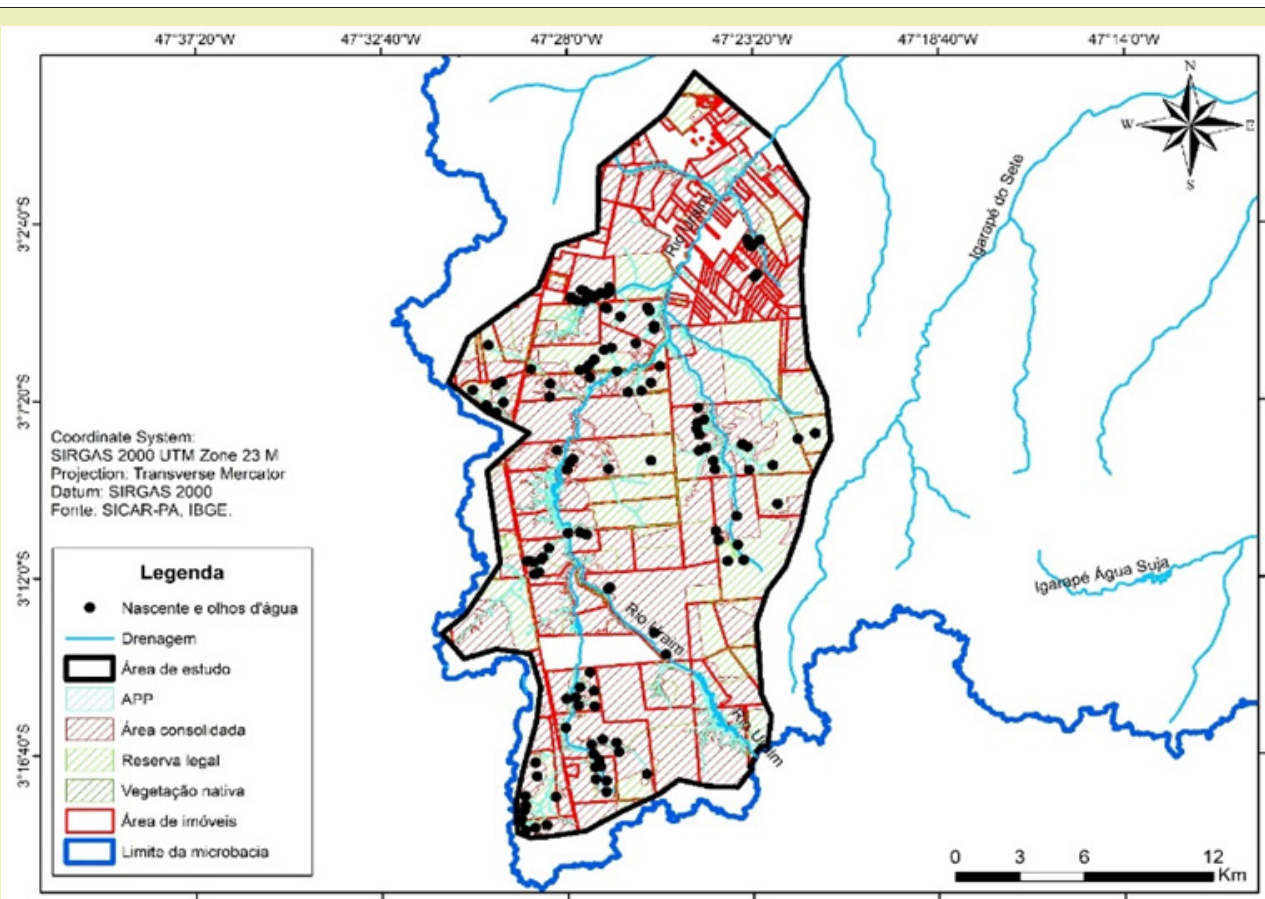

Figure 3: Map of the properties with spring, drainage, APP, etc.

Source: IBGE; ${ }^{8}$ SICAR. ${ }^{22}$

The analysis of the data obtained indicated that in the rural properties located in the polygon of the survey (Figure 3), more than $95 \%$ of the area has an active CAR, the rest has not declared or is pending. Of the declared rural areas around $90 \%$ are superior to 4 fiscal modules, large and medium properties, among which, the percentage of consolidated area varies between $12 \%$ to $97 \%$ of the property.

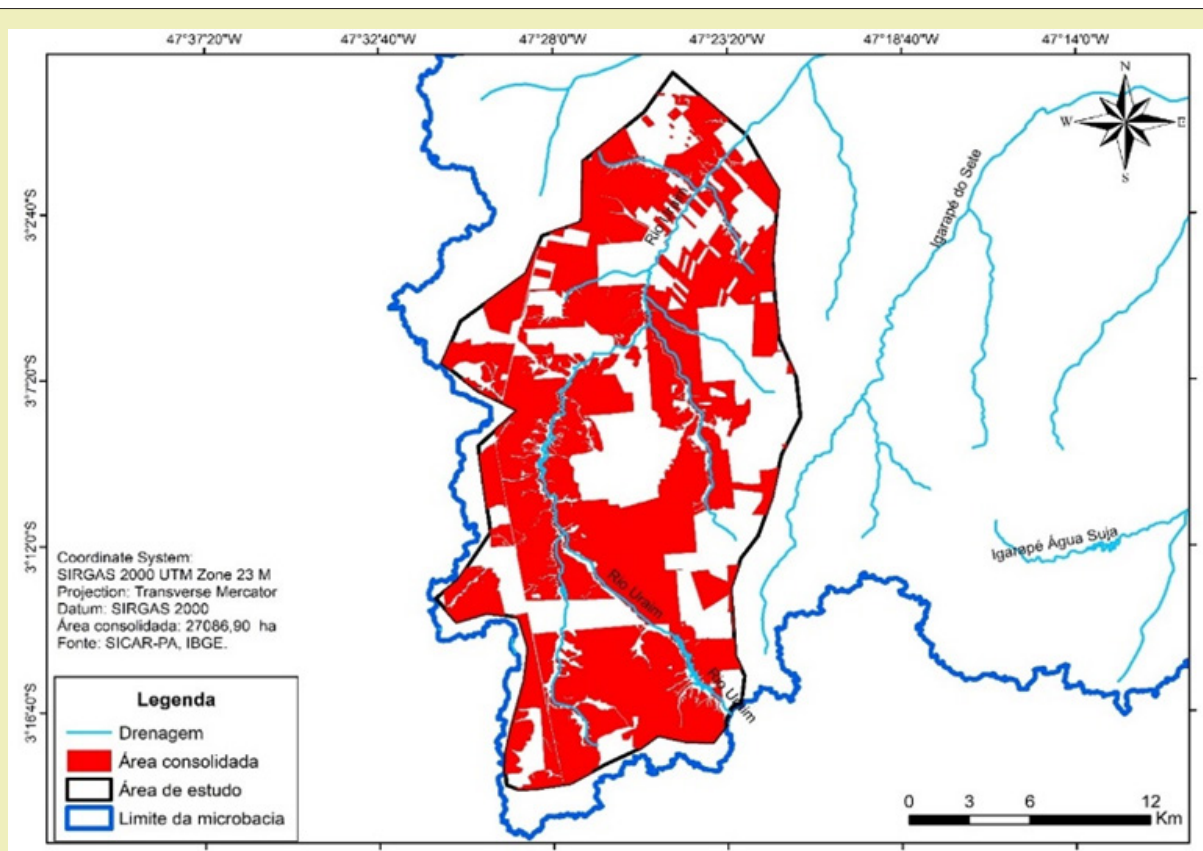

Figure 4: Areas declared consolidated. Paragominas-PA.

Source: IBGE; ${ }^{8}$ SICAR. ${ }^{22}$ 
The Brazilian Forestry Code, conceptualizes a consolidated rural area as: anthropic area with improvements, corrals, buildings and/or human activities pre-existing on July 22, 2008, in use or fallow (area under rest for one or more years). The other rural areas declared to SICAR vary from 3.9484fiscal modules to 0.0155 , being small properties (sites and farms), with percentage of anthropized area of approximately $90 \%$ of the total area declared.

As for the consolidated and declared areas, the data indicated that they are equivalent to $27,086.90$ ha (Figure 4), which represents approximately $62 \%$ of the study area, with diverse land use. It is important to consider the eventual risks that these consolidated areas represent, with possible water scarcity in medium- and long-term plans, in face of climate changes that impact the seasonal variability of Amazon rainfall, ${ }^{2}$ from negative impacts caused by agriculture and livestock freight to other land uses, ${ }^{10}$ and, forested areas favor soil water storage. ${ }^{19}$

Possibly, part of the consolidated areas are compacted, with works, roads, corrals, residences, sheds, pasture (too many animals), agricultural areas (excessive traffic of agricultural machines and implements), etc. which decreases the infiltration of water in the soil, gas exchange between the atmosphere and the soil and increases the risks of water scarcity in quantity and quality for rural owners. This causes a reduction in productivity and will affect the residents of Paragominas-PA. To mitigate this problem, it is necessary to have efficient environmental management on rural properties, with the application of effective techniques in terms of environmental additionality (use and management of soil, water, increased agricultural productivity, livestock, etc.), with effective results, such as the Water Conservative project. ${ }^{20,21}$

The Brazilian Forest Code determines to rural owners the maintenance of APP's, with the environmental function of preserving water resources, biodiversity, facilitating the gene flow of fauna and flora, protecting the soil and ensuring the welfare of human populations (Law No. 12.651/2012). In the study area, according to data from SICAR and IBGE, ${ }^{22}$ on the outskirts of Uraim River, springs, anthropic and natural lakes, perennial water eyes, artificial reservoirs resulting from the damming of water courses, the declared area of APP was 3,993.93ha (Figure 5), and 39 (thirty-nine) properties declared that, in them, APP is in recomposition.

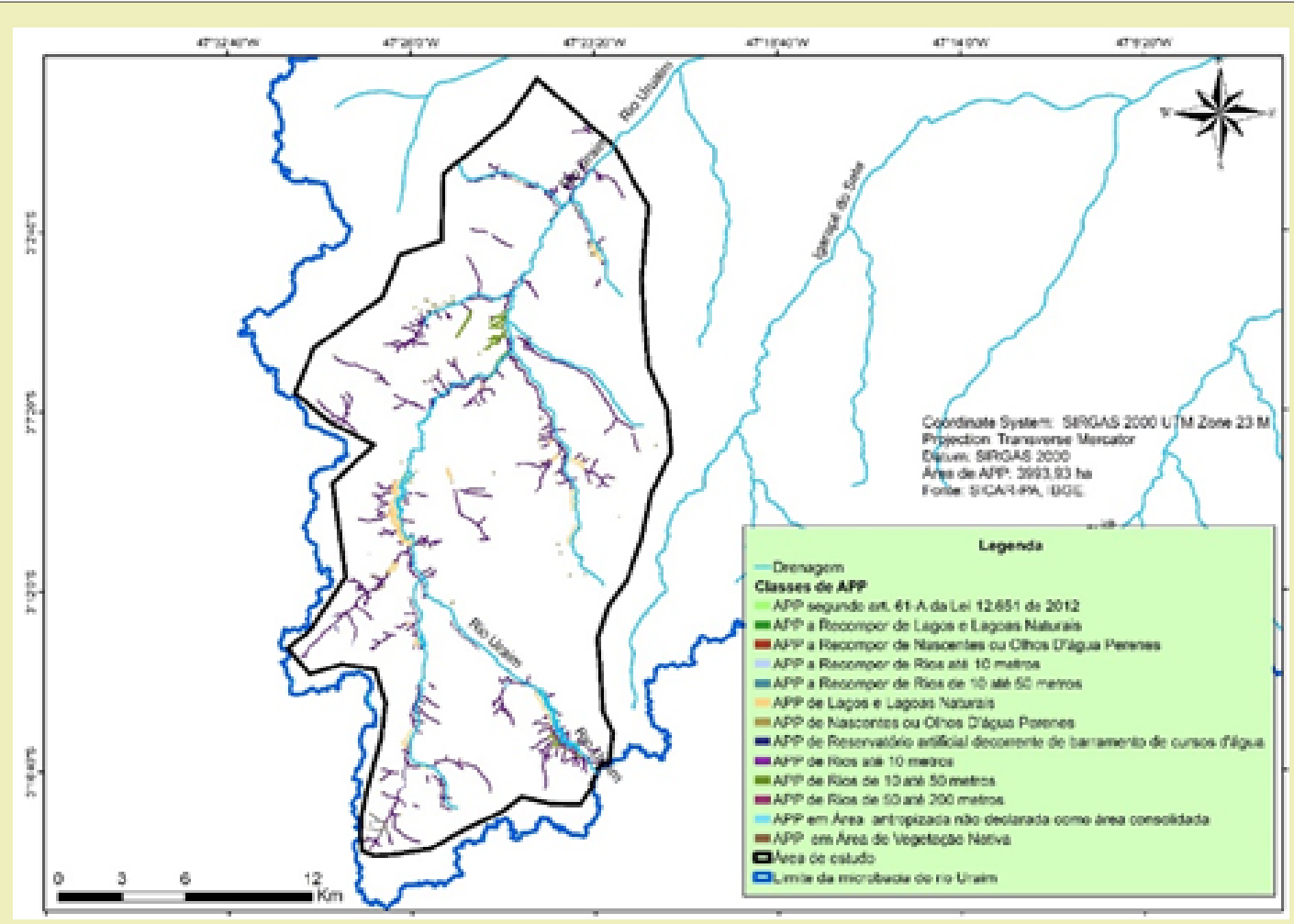

Figure 5: APP according to the Brazilian Forest Code. Source: IBGE; SICAR. $^{22}$

The delimitation of the APP's established in art. 4 of Federal Law 12.651/2012, in rural areas, guarantees the maintenance of marginal strips to the perennial and intermittent natural water courses according to the width, from $10 \mathrm{~m}$ with a requirement of $30 \mathrm{~m}$ of APP, from 10 to $50 \mathrm{~m}$ is determined $50 \mathrm{~m}$ of APP, except for the exceptions determined in art. 61 of the same Law $(61, \S 1,2,3$ and 4 , Law 12.651/2012). In urban areas the Forest Code determines $30 \mathrm{~m}$, however, the urban strip, Uraim colony, which is in the study area does not respect the determination, with residence, bars and changing rooms within the marginal strip of the Uraim River.

Regarding the occupation history of the study area, the analysis of the obtained data indicated that this action caused a high devastation regarding deforestation, with the purpose of guaranteeing land ownership, selling wood, and turning the area into cattle raising. According to Pinto et al. ${ }^{13}$ from 1983 to 1992, Paragominas-PA, 
became the largest cattle producer in the state of Pará, and the study region is on the edge of BR 010, near the urban center, which facilitated access and anthropization. This reflected in the area of native vegetation of the study polygon, according to SICAR and IBGE $^{22}$ the area of declared native vegetation is 15,218 .9ha (Figure 6), which represents about $35 \%$ of the total area.

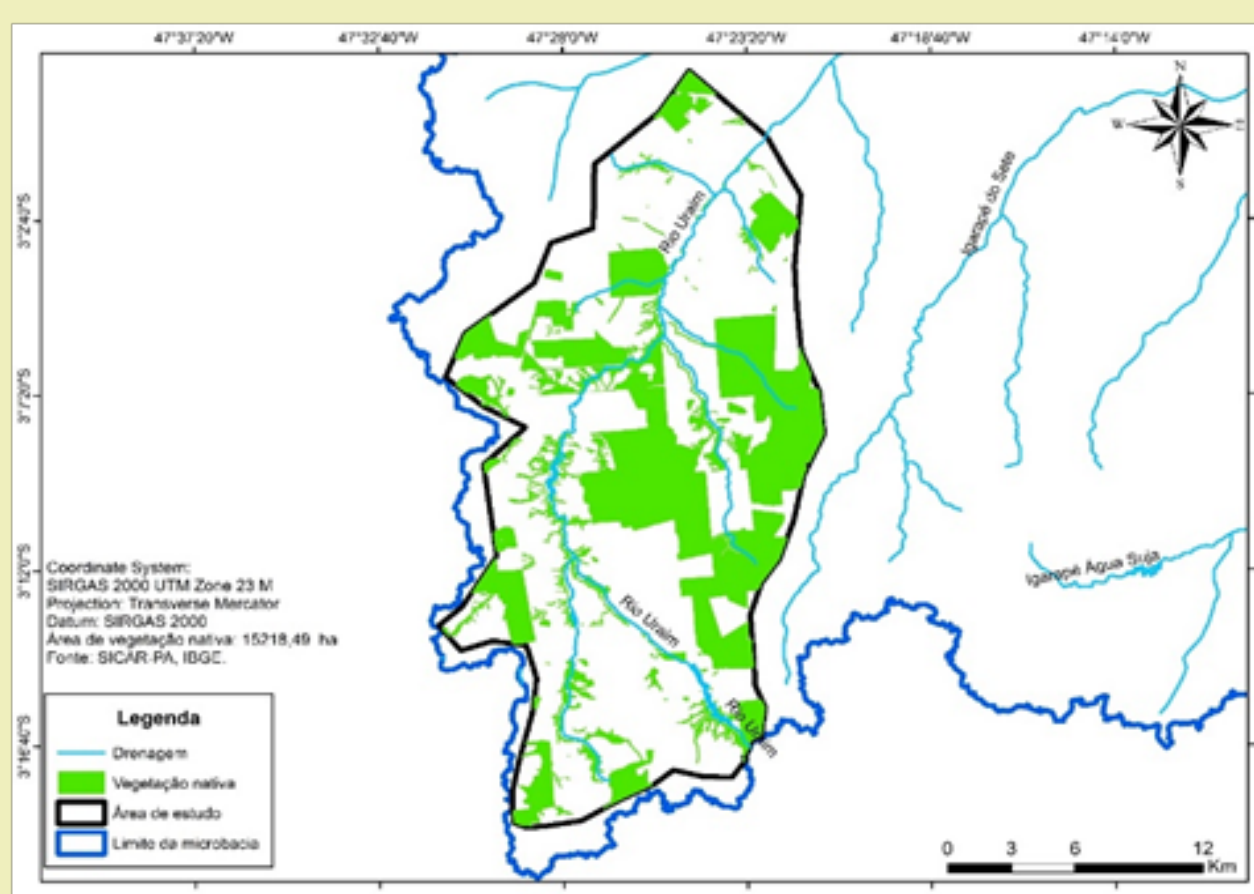

Figure 6: Area of native vegetation. Paragominas- PA. Source: IBGE; ${ }^{8}$ SICAR. ${ }^{22}$

The data analyzed regarding the legal reserve area proposed by rural producers indicated that it was equivalent to $18,166.85 \mathrm{ha}$ (Figure 7), all declared to SICAR-PA, and about 2,948.36ha, to be re- composed via natural regeneration, or insertion of seedlings native to the region.

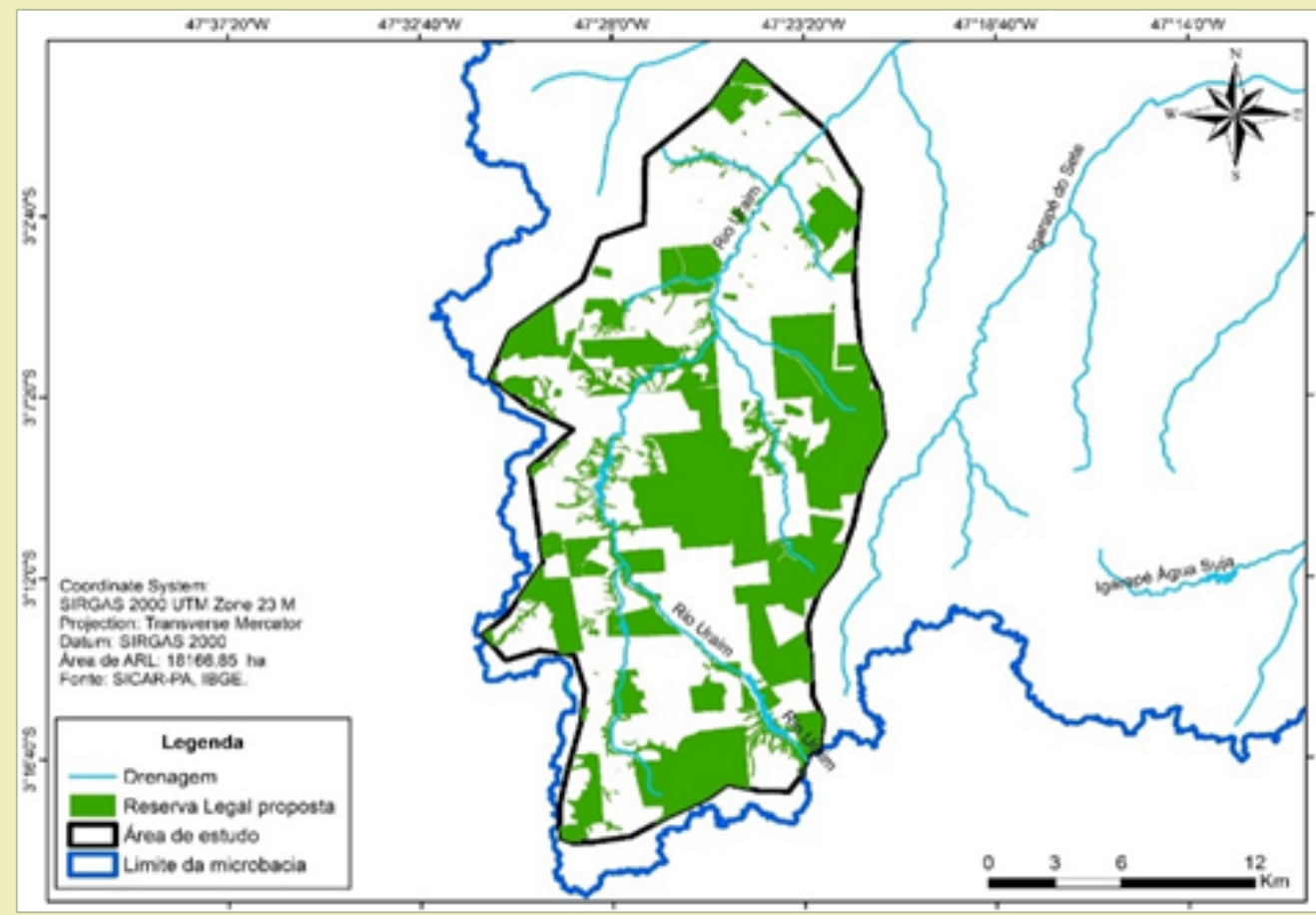

Figure 7: Proposed Legal Reserve. Paragominas- PA Source: IBGE; ${ }^{8}$ SICAR. ${ }^{22}$ 
The data also indicated that other properties were declared to SICAR-PA, as consolidated areas with percentage to regularize, and adopt the alternatives proposed in art. 66, of Law 12.651/2012, which allows to recompose and/or compensate the RL in another area of the same biome.

The data analysis also indicated that the properties (farms and sites) occupy the marginal strip of the water courses of the study area, do not surround the APP in the margins of the rivers and streams, with free access to cattle for dessedentation. Howev- er, these properties are within what is established by the Brazilian Forest Code of 2012 in art. 9 which says: "People and animals are allowed access to the APP to obtain water and to perform activities of low environmental impact.

In relation to the springs, natural outcrops of the water table, the data indicated that they were identified and declared to SICAR-PA, and totaled 131 (Figure 8). Law 12.651/12 determines that in areas around springs and waterholes, regardless of the topographic situation, APP should be mapped within a 50 meter radius. ${ }^{23}$

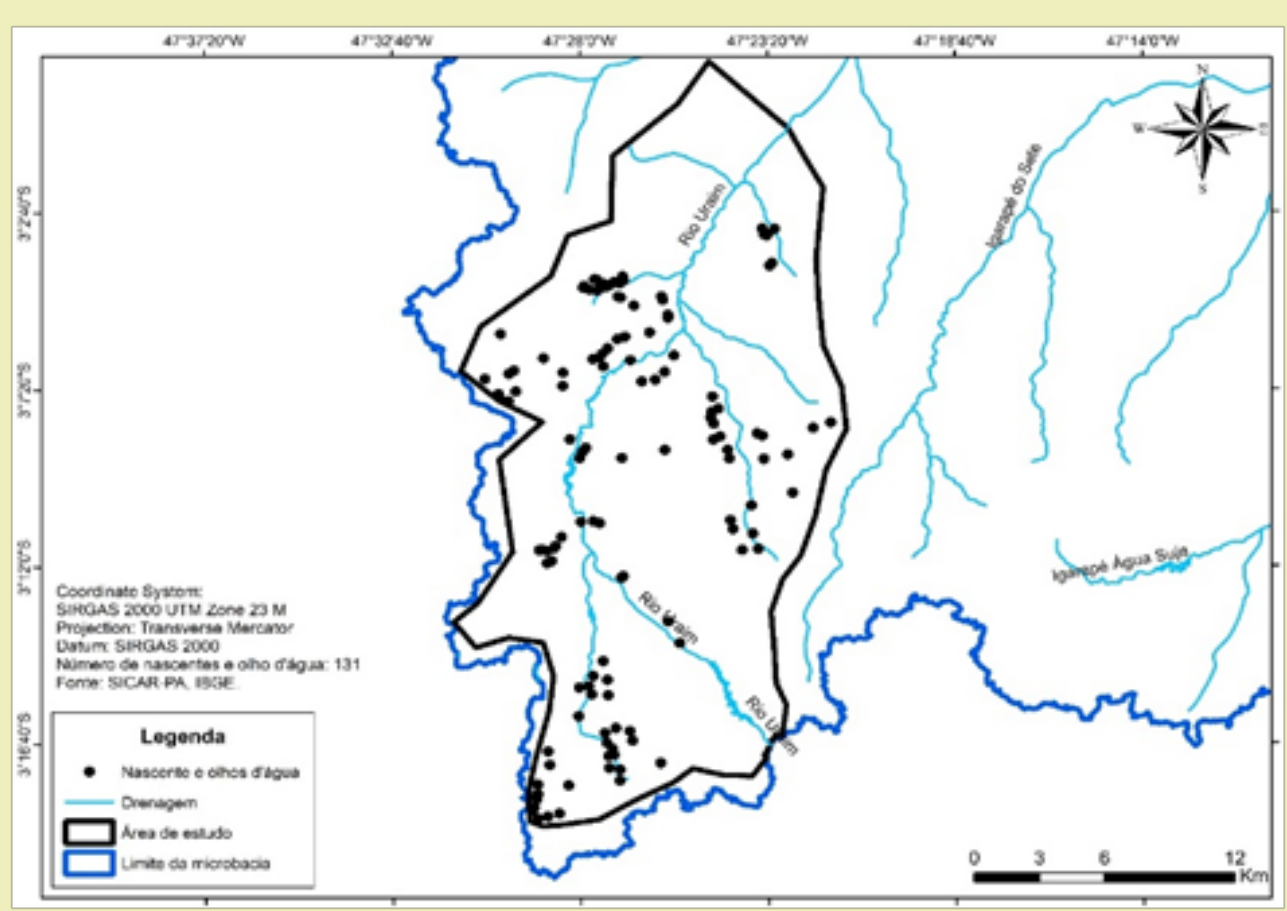

Figure 8: East and Eyes of water on rural properties contained in the studied polygon. Paragominas- PA. Source: IBGE; ${ }^{8}$ SICAR. ${ }^{22}$

It was also verified that, in the study polygon, a consolidated urban area, the Uraim colony, which is about $10 \mathrm{~km}$ from the urban nucleus of Paragominas-PA, on the right bank of the Uraim river, determined in art. 18 of the Municipal Law no 597/2006 - Paragominas Master Plan, as a Neighborhood Unit - UV. The site has more than 50inhabitants/ha and infrastructure with drinking water supply by the company SANEPAR, electricity distribution network, urban cleaning with collection and management of solid waste, primary school, churches, health post, police station, road system and urban transportation, on site visit. ${ }^{24-30}$

However, the system for collecting domestic effluents is deficient, or non-existent, so families, churches and schools dispose of their waste in septic tank or black pit (hole dug directly in the ground covered with wood or concrete), without paying attention to health and environmental risks. This model of waste disposal falls directly into a hole, with access to the ground without the proper protective membrane/geomembrane, part of it infiltrates and another is decomposed by anaerobic bacteria at the bottom of the compartment, which allows environmental contamination of wells, water sources, groundwater, and harms human and animal health. ${ }^{23}$
As for the waste from animals raised on the properties analyzed (cattle, goats, sheep, chickens, pigs, etc.) it was found that they are deposited in the open, subject to the action of rain and wind, so they are carried by the rains to the drainage networks, springs and water sources in the region.

\section{Final Considerations}

The management of water resources is fundamental in the study area, because it represents the possibility of life conservation, maintenance of biodiversity, and meeting the basic needs of human beings living along the Uraim River. The perimeter of study of the Uraim River micro-basin underwent important changes after the 1960s, as a result of disorderly occupation, with fragmentation of the forest, a significant increase in the consolidated area, with several activities that cause negative impacts, sponsored by public banks and military ideologies of occupation and "protection of the Amazon" of the time, however, it was not possible to measure the loss of hydrological environmental services in the area.

Therefore, there is a need to implement an environmental management system in rural and urban properties along the Uraim River, in the study polygon, with fiscal incentives and that makes 
available techniques that increase the economic productivity of the properties, and the protection of the environment. PSA uses assertive methodologies and is a tool that encourages cultural changes of farmers and ranchers, with a view to sustainable development, increased economic productivity with control of land use and water resources, protection of the forest, APP that can mitigate the silting up of the watercourse on the banks of the Uraim River, with appropriate techniques can safeguard the ecological flow of the drainage channels of the river, in order to prevent water shortages to the townspeople of Paragominas-PA.

Originally, the riparian forests of the Uraim River in the study area were characterized by buritiziers (Mauritia flexuosa L.), skulls (Pterodonpubescens Bentharn), açaizeiros (Euterpe oleracea Mart.), aningas (Montrichardiasp) and etc. Over the years and anthropic actions, the banks of the Uraim River have been permeated with grass, exogenous plants, in the urbanized area and in some farms with cattle access for dessedentation, silting of the banks, compaction and degradation of soil and water. To remedy this situation on the banks of the Uraim River it is necessary to surround the banks, insert plant seedlings characteristic of the APP in the region, and implement a system of liquid effluent treatment in the UV, Uraim colony.

In this scenario of environmental change, where the consolidated areas already represent more than $60 \%$ of the study polygon, and the deforestation of forests may interfere with the hydrological cycle, with aggravating, the Amazon region has suffered changes in rainfall patterns. As a result of climate change; in the last 50 years the average increase in land temperature was $1.02^{\circ} \mathrm{C}$, added to the negative impacts of man-made actions in the region.

In contrast, the demand for capturing water from the Uraim River is growing, the company SANEPAR now serves $47 \%$ of the population of the city of Paragominas-PA with treated water, and will meet at the end of $2018100 \%$, the demand for capturing the Uraim River has a flow of $180 \mathrm{~L} / \mathrm{s}$ and will increase to $360 \mathrm{~L} / \mathrm{s}$. There are also multiple uses, competitors, for the development of the regional micro economy with agriculture, animal breeding, slaughterhouse, industry, for food production, also reforestation with monocultures, and to meet the daily needs of rural producers.

The existing tools of environmental management, monitoring of environmental agencies, and municipal law No. 598/2006 and federal law No. 12651/2012, are consistent with the needs, and aims to ensure the maintenance of quantity and improve the quality of water resources, with requirements for preservation of RL on the properties of APA, APP (marginal forests to springs, rivers, etc.).

However, these tools are not consistent with future needs and demands in the provision of environmental services, over the years the properties develop and increase the need for water. In addition, SANEPAR has expanded its treatment and distribution system to meet $100 \%$ of its residents and the city tends to grow.

Therefore, in order to establish the necessary guarantees of environmental management of the properties, with the objective of receiving ecosystem services in the future, it is necessary to act in a coherent and consistent manner, paying attention to economic and ecological issues, with a view to tools that complement the current ones, without compromising the bases of sustainability of the rural properties, with emphasis on those that have a direct relationship with the Uraim River, the river banks and tributaries or springs, in the area of interest, upstream from the point of capture of the company SANEPAR.

The PSA system can be a means of propagating adequate methods and techniques of environmental management, with a view to improving health issues in urbanized areas of the communities, industries with the insertion of a sewage collection and treatment system, and, in remote regions, farms, sites attentive to the change of waste disposal from black pits to septic tanks.

Furthermore, the PSA study as a strategic tool for the environmental conservation of a micro-basin in the Amazon region was intended to provide public authorities and other interested parties with data that demonstrate the need to act today in order to guarantee the SANEPAR company sufficient flow to meet the needs of its residents and the multiple use of water from the Uraim River to others with growing demand, without compromising existing ecosystem services and biodiversity.

In view of all that has been exposed, the company SANEPAR is the main actor in the play, and can, with political will, start the project as one of the funding sources. As for the others, it is important to involve the Municipal Secretary of Green and Environment of Paragominas (SEMMA), the municipality of Paragominas, the rural union of Paragominas and the Public Ministry which are the representatives of both sides of the business, rural producers and beneficiaries.

By joining forces, it is possible to raise funds at the Vale Foundation and the World Development Bank. And finally, it is very important to establish partnerships with NGOs, the Instituto do Homem e Meio Ambiente da Amazônia (IMAZON) and The Nature Conservancy (TNC) aiming at technical knowledge and expertise to foment and implement PES with environmental management of the micro basin in an efficient and assertive manner.

\section{Recommendation for future work}

It is important to analyze PSA models in a qualitative and quantitative way, which meet the desires and perspectives of rural owners, service providers, and, to users, beneficiaries of the services provided. In this context, it is essential to listen to the interested parties, consider recommendations, pay attention to the needs and value the services to be provided in an assertive and deductive manner.

\section{Acknowledgments}

None.

Funding

None. 


\section{Conflicts of interest}

Author declares that there is no conflict of interest.

\section{References}

1. Medeiros RLS. Evaluation of a hydrographic basin as a functional unit of natural resources. Dissertation (Master in Agronomy) - Department of Plant Production, Universidade Estadual Paulista-UNESP, Jaboticabal, São Paulo. 2018.

2. Souza PJOP. Impacts of climate change on soybean crops in the northeast of the state of Pará. Revista Brasileira de Agricultura Irrigada strength. 2018;12(2):2454-2467.

3. Souza VVC. Payment for water resources environmental services in urban areas: potential perspectives from a water quality recovery program in the city of São Paulo. Cad Metrop Sao Paulo. 2018;20(42):493-512.

4. Pagiola S, Glehn HCV, Taffarello D. Experiences of Payments for Environmental Services in Brazil. São Paulo (State). Secretaryof the Environment/Biodiversity and Natural Resources Coordination. 2013.

5. Moreira FTC. Payment for environmental services-Case study: Pratigi water-producing project, Ibirapitanga, BA. Graduation work (Bachelor in Forestry Engineering) Federal University of Recôncavo da Bahia - UFRB, Cruz das Almas. 2018.

6. Forest Trends, Grupo Katoomba, UNEP. Payments for environmental services: a manual on how to get started. UNON Publishing Services Section, Nairobi, Kenya. 2008.

7. Manfredini FN. Application of environmental legislation in the economic valuation of environmental services in the Environmental Protection Area (APA) of Itupararanga. 2018. Thesis (PhD in Environmental Sciences)Institute of Science and Technology, UniversidadeEstadualPaulista "Júlio de Mesquita Filho", Sorocaba. 2018.

8. IBGE. Brazilian Institute of Geography and Statistics. Population of Paragominas municipality. 2018.

9. IBGE. Brazilian Institute of Geography and Statistics. 2018.

10. Simões IOPS. Analysis of pasture intensification in the municipality of Paragominas-PA between the years 2014 and 2017.2018. Dissertation (Master in Agricultural Engineering)-Faculty of Agricultural Engineering, State University of Campinas, Campinas. 2018.

11. Matins HD. Mapping of Paragominas-Pa soil cover with high resolution satellite images for the Rural Environmental Registry (CAR). In: SIMPÓSIO BRASILEIRO DE SENSORIAMENTO REMOTO.16. 2013.

12. ANA. National Water Agency. Availability and demands of Water Resources in Brazil. 2005.

13. Pinto A.Socioeconomic and Forestry Diagnosis of the municipality of Paragominas. Institute of Man and Environment of the Amazon (IMAZON), Belém. 2009;1-65.
14. Paragominas. City Hall. Green Municipality Project. Paragominas. 2011.

15. IMAZON. Institute of Man and Environment of the Amazon. Eleven cities are already following the Paragominas model against deforestation in the Amazon. Belem. 2013.

16. Matias-Pereira J. Scientific research methodology manual. 4 ed. São Paulo: Atlas. 2016.

17. Sakamoto CK, Silveira IO. How to do scientific initiation projects. São Paulo: Paulus. 2014.

18. Sanepar. Paragominas Sanitation Agency. Expansion of the water supply. Paragominas. 2018.

19. Carvalho SP, De Souza JRS, Makino M. Observations and Estimates of thermal properties of soil under forest and pasture in eastern Amazonia. Brazilian Journal of Meteorology. 2013;28(3):331-340.

20. Chaves HML. Quantification of the environmental benefits and financial compensation of the "Water Producer Program" (ANA): II. Application. Brasilia. 2004.

21. Chiodi RE, Marques PEM. Public policy for payment for environmental services for the conservation of water resources: origins, actors, interests and results of institutional action. Electronic Magazine System - SER/ Universidade Federal do Paraná - UFPR, Curitiba. 2018;45.

22. Sicar. Sistema De Cadastro Ambiental Rural. Imóveis. Estado - Pará. Paragominas. 2018.

23. Cardoso RNC. Analysis of vulnerability and risk to contamination of semi-confined aquifers on the island of Cotijuba/PA. Belém. 2018.

24. Araujo ER, Olivieri RD, Fernandes FRC. Mining activity generates wealth and negative impacts on communities and the environment. In: Fernandes FRC, Alamino RCJ, Araujo ER, Editors. Mineral resources and community: Human, socio-environmental and economic impacts. Rio de Janeiro: CETEM/MCTI. 2014;1-12.

25. Costa AC, Oliveira IC, Ravena N. Institutional voices and domination speeches: analysis of large hydroelectric projects in the Amazon. Famecos magazine media, culture and technology. 2017;24(2).

26. Fleury LC, Almeida JP. The construction of the Belo Monte hydroelectric plant: Environmental conflict and the development dilemma. LUME DIGITAL REPOSITORY UFRGS, São Paulo. 2013;XVI(4):141-158.

27. Oliveira FR. Hydroenvironmental quality of springs in the Florestan Fernandes settlement. 2018. Dissertation (Master in Forest Sciences) Federal University of Espírito Santo, Jerônimo Monteiro. 2018.

28. PBMC. Brazilian Panel on Climate Change. 2011.

29. Paragominas. Municipal Law of Paragominas No. 597/2006a. Master plan for urban development (PDDU) of the municipality of Paragominas. 2006.

30. Paragominas. Law No. 597, of October 20, 2006b. Creates the Environmental Protection Area-APA of the Uraim River that regulates the use and occupation of the soil. Legislation of the city of Paragominas, Pará. 2018. 